\title{
EDUCORETAX
}

Volume 1 No. 2, Juni 2021

\section{Tinjauan Penerapan Open Space di Kantor Pelayanan Pajak Pratama Tangerang Timur}

\author{
Laras Putri Widi Winantu
}

larasptr54@gmail.com, Politeknik Keuangan Negara STAN

\begin{abstract}
An Open space is one of the important aspects to support the comfort of employees in doing work so as to produce more optimal performance. However, previous research has shown that not all work units in Tax Directorate General can implement an open space policy. This is due to employees who have difficulty in organizing physical files, unsupported infrastructure, different types of work and business processes. Thus, this study aims to find out the application, impact, challenges, and solutions of open space implementation in Tax Service Office East Tangerang. This study uses qualitative method which is interview and visual method with participant sample selection based on purposive sampling method. The type of interview used is a semi-strucured interview that is the interviewer prepares a key question as a guide before the interview. Meanwhile, Visual method is used as a method of collecting data in the form of photos and images for supporting data. The results showed that although the application of open space was responded positively by employees at Tax Service Office East Tangerang, but this application was also inseparable from the positive and negative impacts it had. In addition, there are challenges in the application of open space in Tax Service Office East Tangerang as well as solutions that can solve it so that the application of open space can be more optimal.
\end{abstract}

Keywords : open space, qualitative research, visual method, purposive sampling, semi-strucured interview.

\begin{abstract}
Abstrak
Tata ruang kantor terbuka atau open space merupakan salah satu aspek penting untuk menunjang kenyamanan pegawai dalam melaksanakan pekerjaan sehingga dapat menghasilkan kinerja yang lebih optimal. Namun, penelitian terdahulu menunjukkan bahwa belum semua unit kerja di DJP siap untuk menerapkan kebijakan open space. Hal ini disebabkan oleh pegawai yang masih kesulitan dalam mengorganisasikan berkas-berkas fisik, infrastruktur yang belum mendukung, serta jenis pekerjaan dan proses bisnis yang berbeda. Dengan demikian, penelitian ini bertujuan untuk mengetahui penerapan, dampak, tantangan, dan solusi dilaksanakannya open space di KPP Pratama Tangerang Timur. Penelitian ini menggunakan metode kualitatif yaitu wawancara dan visual method dengan pemilihan sampel partisipan berdasar pada metode purposive sampling. Jenis wawancara yang digunakan adalah semi-strucured interview yaitu pewawancara menyiapkan pertanyaan kunci sebagai panduan sebelum dilaksanakannya wawancara. Sementara itu, visual method digunakan sebagai metode pengumpulan data berupa foto dan gambar untuk data pendukung. Hasil penelitian menunjukkan bahwa meskipun penerapan open space direspons positif oleh pegawai di KPP Pratama Tangerang Timur, tetapi penerapan ini juga tidak terlepas dari dampak positif dan negatif yang ditimbulkannya. Selain itu, terdapat tantangan dalam penerapan open space di KPP Pratama Tangerang Timur serta solusi yang bisa memecahkannya dapat lebih optimal.
\end{abstract}

Kata Kunci : open space, penelitian kualitatif, visual method, purposive sampling, semi-strucured interview

\section{PENDAHULUAN}

Tahun demi tahun, tantangan yang dihadapi oleh organisasi pemerintah akan semakin beragam. Tantangan tersebut tentu akan memberikan dampak pada organisasi sehingga mendorong organisasi untuk melakukan berbagai upaya guna menyesuaikan diri dengan segala kemungkinan yang dihadapi. Salah satu upaya yang dilakukan oleh organisasi untuk menghadapi segala macam tantangan tersebut adalah dengan memaksimalkan kemampuan sumber daya manusianya, agar dapat mencapai outcome organisasi yang optimal. Hal tersebut juga dilakukan oleh Kementerian Keuangan. Sebagai salah satu organisasi pemerintah, Kementerian Keuangan selalu berupaya untuk dapat menyesuaikan diri dengan segala tantangan yang dihadapi dengan cara memaksimalkan sumber daya manusia atau pegawainya agar dapat mencapai kinerja yang maksimal.

Memaksimalkan kinerja sumber daya manusia berarti juga memaksimalkan kinerja organisasinya, karena sumber daya manusia atau pegawai dalam suatu organisasi merupakan 


\section{EDUCORETAX}

Volume 1 No. 1, Maret 2021

kekuatan dalam sebuah organisasi itu sendiri. Seperti yang dijelaskan oleh Masram dan Mu'ah (2017) bahwa aset penting yang dimiliki oleh suatu organisasi adalah sumber daya manusia atau pegawai. Untuk mengelola aset penting tersebut, tentu organisasi termasuk juga Kementerian Keuangan akan melakukan berbagai cara agar para pegawai dapat termotivasi untuk lebih produktif dan melakukan pekerjaannya dengan lebih baik. Salah satu caranya adalah dengan membuat suasana lingkungan kerja atau kantor menjadi lebih nyaman sehingga mendukung aktivitas pegawai agar dapat menghasilkan kinerja yang optimal.

Kenyamanan lingkungan kerja atau kantor dapat berasal dari berbagai aspek, salah satunya adalah aspek penyusunan layout tempat kerja. Hasil survei yang dilakukan oleh Saleem, dkk. (2012) terhadap dua ribu karyawan dari berbagai tingkat organisasi di Pakistan menemukan bahwa tata ruang kantor yang baik dan nyaman akan memengaruhi sikap dan produktivitas kerja karyawan dalam organisasi tersebut. Hal ini sejalan dengan penelitian Afifah (2019) yang menjelaskan bahwa setiap kantor memerlukan penyusunan layout tempat kerja dan perlengkapan kantor dengan sebaik-baiknya agar para pegawai dapat merasa nyaman dalam melakukan pekerjaannya sehingga mereka dapat menghasilkan kinerja yang maksimal.

Sejalan dengan hal itu, Kementerian Keuangan telah menginisiasi suatu kebijakan untuk mewujudkan layout tempat kerja yang dapat mendukung pegawai untuk melakukan diskusi, brainstorming, dan aktivitas lain yang dapat meningkatkan kinerja dan produktivitas pegawai. Kebijakan tersebut tercantum dalam Keputusan Menteri Keuangan Nomor 302/KMK.01/2019 yang telah diperbarui dengan Keputusan Menteri Keuangan Nomor 91/KMK.01/2021 tentang Implementasi Inisiatif Strategis Program Reformasi Birokrasi dan Transformasi Kelembagaan Kementerian Keuangan. Salah satu tema sentral yang akan diterapkan adalah Penguatan Budaya Organisasi: The New Thinking of Working dengan salah satu terobosan berupa program Activity Based Workplace yang mencakup penerapan open space. Sebagaimana dijelaskan dalam KMK 91/KMK.01/2021, kebijakan penerapan open space tidak hanya dilakukan di lingkup kantor Kementerian Keuangan, tetapi juga di seluruh Unit Eselon 1 Kementerian Keuangan, termasuk Direktorat Jenderal Pajak (DJP).

Dalam penerapannya, open space memfasilitasi pegawai untuk memiliki ruang kerja bersama yang disesuaikan dengan jumlah pegawai. Seperti yang dijelaskan oleh Hedge (1982) bahwa istilah open space mengacu pada penataan ruang kantor yang lebih fleksibel serta tidak ada dinding yang memisahkan, atau pemisah hanya berupa partisi rendah yang memudahkan aktivitas pegawai. Ruang kerja berupa open space meliputi berbagai fasilitas pendukung lain, seperti collaboration space (ruang rapat kecil, ruang rapat besar, dan perangkat pendukung video conference), leisure area (dapur atau ruang bersama), care room serta area penyimpanan atau loker untuk pegawai (CTO, 2020). Konsep ruang kerja berupa open space diharapkan dapat lebih memberdayakan pegawai, bukan hanya sekadar tempat di mana pegawai wajib berada, tapi juga harus bisa mendukung berbagai aktivitas pegawai.

Selain dapat mendukung aktivitas pegawai, open space juga merupakan bentuk tata ruang kerja yang dapat mendorong pegawai untuk berinteraksi satu sama lain. Tata ruang kerja yang terbuka dengan cara meminimalisasi partisi memungkinkan adanya komunikasi antarpegawai yang lebih baik agar para pegawai dapat berkolaborasi untuk mencapai kinerja yang optimal, yang tentu akan berdampak pada organisasi (Prabawani \& Sungkar, 2018). Hal tersebut sejalan dengan apa yang disampaikan oleh Kornberger dan Clegg (2004) bahwa tempat kerja memiliki andil untuk membentuk interaksi antarmanusia dan memengaruhi perilaku serta kepuasan dalam bekerja. Hal ini sesuai dengan tujuan dari penerapan open space itu sendiri, yaitu mengubah budaya organisasi sektoral menjadi kolaboratif, di mana para pegawai dapat dengan mudah berinteraksi dan berdiskusi dengan pegawai lain untuk mempermudah penyelesaian pekerjaan (CTO, 2020). 


\section{EDUCORETAX}

Volume 1 No. 2, Juni 2021

Sebuah studi yang dilakukan oleh Irving (2016) pada tiga organisasi berbeda di Australia menunjukkan bahwa lingkungan kerja dengan layout open space dapat meningkatkan minat para pegawai untuk melakukan kolaborasi dengan pegawai lain. Dengan demikian, para pegawai akan terbantu dalam penyelesaian pekerjaannya. Interaksi adalah hal yang sangat diperlukan untuk menjaga hubungan antarpegawai serta mendorong pegawai untuk dapat bertukar pikiran perihal pekerjaan yang tentu akan berdampak baik pada produktivitas pegawai.

Studi lain juga dilakukan oleh Santoso (2020) pada unit kerja Direktorat Jenderal Pajak, yaitu Direktorat Kepatuhan Internal dan Sumber Daya Aparatur (KITSDA) dan Kantor Pelayanan Pajak (KPP) Pratama Medan Kota. Studi tersebut tidak secara spesifik fokus membahas open space, tapi juga menguraikan bentuk flexible working arrangement lainnya seperti flexi time dan working from home. Hasil penelitian tersebut menjelaskan bahwa di unit kerja yang sudah menerapkan open space (yaitu pada salah satu subdirektorat di Direktorat KITSDA), para pegawai merasa lebih nyaman dalam melaksanakan pekerjaan dengan tata ruang kantor yang terbuka. Kenyamanan tersebut memberikan mereka motivasi yang lebih baik dalam bekerja. Motivasi dalam bekerja merupakan suatu hal yang harus dimiliki oleh setiap pegawai, karena semakin tinggi seorang pegawai memiliki motivasi dalam pekerjaannya maka secara tidak langsung akan berdampak positif terhadap peningkatan kinerja pegawai tersebut. Penelitian tersebut juga menunjukkan adanya peningkatan kolaborasi, produktivitas, dan kepuasan kerja pegawai di unit kerja yang telah menerapkan open space.

Di samping keberhasilan tersebut, penelitian Santoso (2020) juga menemukan tantangan yang dihadapi oleh pegawai dalam menjalankan konsep open space. Beberapa tantangan yang dirasakan antara lain kebutuhan ruang privasi bagi pegawai dan kesulitan dalam melakukan standardisasi tata ruangan karena terdapat perbedaan di setiap gedung kantor. Selain tantangan tersebut, terdapat potensi resistansi dari pegawai di unit vertikal yang belum menerapkan open space. Pegawai di KPP yang menjadi objek penelitian Santoso (2020) memandang belum semua unit kerja di DJP siap untuk menerapkan kebijakan open space karena kesulitan pegawai untuk mengorganisasikan berkas-berkas fisik, infrastruktur yang belum mendukung penerapan open space, serta jenis pekerjaan dan proses bisnis yang berbeda.

Pandangan para pegawai KPP dalam penelitian terdahulu tampaknya berbeda dengan pendapat Kepala KPP Pratama Tangerang Timur, yang telah menerapkan konsep open space di KPP tersebut secara bertahap sejak tahun 2018. Dalam sebuah artikel di Majalah Pajak, Kepala KPP Pratama Tangerang Timur menjelaskan bahwa walaupun pada awalnya pegawai KPP Pratama Tangerang Timur merasa kurang nyaman dengan konsep open space, tata ruang kerja yang terbuka dipercaya dapat berdampak pada kinerja, meningkatkan sinergi, menjaga integritas, dan memupuk budaya disiplin kerja (Hariani, 2019). Hasil penelitian sebelumnya yang menunjukkan keberhasilan dan berbagai tantangan dalam penerapan open space, serta adanya perbedaan pandangan antara para pegawai di KPP yang berbeda mengenai penerapan konsep open space, membuka ruang untuk dilakukan penelitian lebih lanjut mengenai tata ruang kerja berkonsep terbuka ini. Selain itu, penelitian dengan lokasi di KPP akan melengkapi penelitian sebelumnya yang sudah pernah dilakukan di unit Kantor Pusat DJP, mengingat jumlah pegawai, jenis pekerjaan, dan proses bisnis di KPP berbeda dengan Kantor Pusat.

KPP Pratama Tangerang Timur dipilih sebagai objek penelitian karena KPP tersebut telah melaksanakan kebijakan open space sejak tahun 2018 secara bertahap. Pada awalnya, konsep ini diterapkan di ruang kerja Seksi Pengawasan dan Konsultasi (Waskon) II hingga IV, Seksi Penagihan, dan Seksi Pemeriksaan (Hariyani, 2019). Hingga tahun 2020, konsep open space telah berhasil diterapkan secara merata di semua seksi.

Berdasarkan hal-hal tersebut, tujuan penelitian ini adalah mengetahui penerapan open space, dampak penerapan open space, tantangan dalam penerapan open space, dan cara mengatasi tantangan dalam penerapan open space di KPP Pratama Tangerang Timur. 


\section{EDUCORETAX}

Volume 1 No. 1, Maret 2021

\section{KAJIAN PUSTAKA \\ Organisasi}

Rivai dan Mulyadi (2007) menjelaskan organisasi adalah sekelompok orang yang saling ketergantungan satu sama lain yang secara bersama-sama memfokuskan usaha mereka untuk mencapai tujuan atau untuk menyelesaikan suatu tugas tertentu. Teori tersebut sejalan dengan yang disampaikan oleh Robbins dan Coulter (2018) bahwa organisasi merupakan susunan orang-orang yang sengaja dibentuk guna mencapai tujuan tertentu.

Dalam suatu organisasi terdapat beberapa karakteristik yang membedakan satu organisasi dengan organisasi lainnya. Robbins dan Coulter (2018) menjelaskan beberapa karakteristik tersebut. Karakteristik pertama adalah organisasi memiliki tujuan yang jelas. Tujuan ini biasanya dinyatakan sebagai suatu tujuan yang ingin dicapai oleh organisasi karena pada dasarnya tujuan organisasi yang satu pasti berbeda dengan tujuan organisasi lain. Karakteristik kedua, organisasi terdiri dari lebih dari satu orang. Organisasi memerlukan beberapa orang untuk dapat melakukan pekerjaan dalam rangka mencapai tujuan organisasi tersebut. Karakteristik ketiga adalah setiap organisasi mengembangkan struktur atau bentuk yang disengaja di tempat anggota melakukan pekerjaan mereka untuk memenuhi kebutuhan anggota organisasi tersebut. Hal ini dilakukan agar setiap anggota organisasi dapat melaksanakan pekerjaannya.

Berdasarkan penjelasan di atas, Kantor Pelayanan Pajak Pratama Tangerang Timur dapat dikatakan sebagai suatu organisasi, karena telah memenuhi kriteria sebagai suatu organisasi, yaitu memiliki anggota organisasi atau pegawai yang lebih dari satu, memiliki tujuan organisasi, serta terdapat pembentukan struktur organisasi yang mempermudah pembagian pekerjaan sehingga diharapkan dapat memudahkan pegawai dalam melakukan pekerjaan dalam rangka mencapai tujuan organisasi tersebut.

\section{Desain Organisasi}

Robbins dan Coulter (2018) menjelaskan desain organisasi adalah pembentukan ataupun perubahan suatu struktur organisasi. Dalam prosesnya, desain organisasi ini melibatkan enam hal utama, yaitu spesialisasi kerja, departementalisasi, rantai komando, rentang kendali, sentralisasi dan desentralisasi, serta formalisasi organisasi. Pembagian porsi atas keenam hal utama tersebut dapat menjadikan suatu organisasi memiliki desain organisasi tradisional ataupun desain organisasi modern. Penggunaan dari kedua desain ini bergantung pada kebutuhan tiap-tiap organisasi.

\section{Desain Organisasi Tradisional}

Desain organisasi yang pertama adalah desain organisasi tradisional. Robbins dan Coulter (2018) menjelaskan bahwa desain organisasi tradisional merupakan salah satu desain organisasi yang umum dan memiliki tiga jenis struktur organisasi. Struktur pertama adalah struktur sederhana, struktur ini memiliki departementalisasi rendah, rentang pengendalian yang luas, wewenang yang tersentralisasi pada satu orang, dan dengan formalitas yang lebih sedikit.

Dalam perjalanannya, sebuah organisasi akan mengalami perkembangan, baik karena adanya penambahan pegawai atau mengalami perubahan-perubahan lain yang menuntut manajer atau atasan untuk mengubah struktur organisasi tersebut. Terdapat dua struktur lain yang dapat menjadi opsi selain struktur sederhana dalam desain organisasi tradisional, yaitu struktur fungsional dan struktur divisional.

Menurut Robbins dan Coulter (2018), struktur fungsional merupakan struktur organisasi dengan departementalisasi berdasarkan fungsi atau tugas yang serupa, seperti fungsi keuangan, penelitian dan pengembangan produk, sumber daya manusia, serta fungsi lain yang diperlukan dalam suatu organisasi. Kelebihan dari struktur fungsional adalah organisasi dapat menekan biaya yang dikeluarkan karena pekerjaan yang sudah terspesialisasi, sedangkan salah satu 


\section{EDUCORETAX}

Volume 1 No. 2, Juni 2021

kelemahannya adalah spesialisasi dapat menyebabkan pegawai memiliki pemahaman yang terbatas tentang pekerjaan lain yang ada di unit organisasi tersebut.

Struktur organisasi lainnya juga dijelaskan oleh Robbins dan Coulter (2018), yaitu struktur divisional yang merupakan struktur yang terdiri dari unit atau divisi yang diatur oleh manajer yang memiliki otoritas pada unit atau divisi tersebut. Dalam penerapan struktur ini, organisasi hanya bertindak sebagai pengawas dalam rangka mengoordinasikan pekerjaan tiap unit atau divisi serta pemberi dukungan di organisasi.

\section{Desain Organisasi Modern}

Perkembangan zaman menyebabkan organisasi harus dapat menyesuaikan diri dan beradaptasi dengan berbagai tuntutan yang terjadi. Robbins dan Coulter (2018) menjelaskan penyesuaian itu dapat dilakukan dengan beberapa cara, seperti menciptakan lingkungan kerja yang lebih kolaboratif dan membuat pengaturan kerja yang lebih fleksibel. Penyesuaian tersebut dapat dilakukan salah satunya adalah dengan mengubah desain dan struktur organisasi menjadi desain organisasi modern agar lebih dinamis sehingga dapat mengikuti setiap tuntutan serta perubahan yang terjadi. Robbins dan Coulter (2018) menyebutkan bahwa desain organisasi modern dibagi menjadi beberapa bentuk, yaitu (1) Organisasi dengan Struktur Tim; (2) Organisasi dengan Struktur Matriks dan Proyek; (3) Organisasi Tanpa Sekat; (4) Telecommuting; (5) Compressed workweeks; dan (6) Tenaga Kerja Kontingen.

Robbins dan Coulter (2018) dalam bukunya juga menjelaskan beberapa desain organisasi tersebut memiliki kelebihan yang belum dimiliki oleh desain organisasi tradisional. Kelebihan tersebut antara lain pegawai yang lebih diberdayakan dan dilibatkan dalam organisasi, peningkatan fleksibilitas organisasi dalam merespons perubahan, pengambilan keputusan yang lebih cepat sehingga akan memudahkan para pegawai untuk melaksanakan pekerjaannya, organisasi lebih responsif terhadap perubahan-perubahan yang terjadi, serta dapat mendayagunakan bakat yang dimiliki oleh pegawai.

Selain kelebihan diatas, Robbins dan Coulter (2018) juga menyebutkan bahwa beberapa jenis desain organisasi modern memiliki kelemahan seperti tingkat terjadinya konflik antarpegawai lebih tinggi, tidak adanya rantai komando yang jelas, kurangnya rentang kendali dalam organisasi, serta sulitnya komunikasi di organisasi tersebut.

\section{Flexible Working Arrangements}

Konsep tempat kerja yang berkelanjutan dan fleksibel merupakan salah satu isu terkini dalam desain organisasi. Pengaturan kerja yang fleksibel dibutuhkan pada saat ini agar organisasi dapat dengan cepat dan efektif mengakomodasi berbagai perubahan yang terjadi di masa depan serta agar dapat memenuhi segala bentuk persaingan bisnis. Penyusunan tempat kerja yang lebih fleksibel tersebut diharapkan dapat meningkatkan produktivitas individu dan perusahaan, menjaga kesehatan para karyawan, dan menjaga lingkungan bekerja agar tetap baik (Hassanain, 2006).

Dalam studinya, Hassanain (2006) menjelaskan fleksibilitas yang dimaksud merupakan konsep mengenai letak fisik dan fungsi dari ruang kerja, bukan tentang di mana dan kapan pegawai akan melakukan pekerjaannya. Hal ini dapat diartikan bahwa konsep fleksibilitas ruang kerja merupakan konsep di mana perusahaan mempersiapkan ruangan terbuka, besar, dan dapat memfasilitasi pegawai untuk bisa bekerja di mana saja dalam ruangan tersebut. Lebih lanjut dijelaskan oleh Arge (2005) bahwa fleksibilitas diartikan sebagai kemampuan sebuah ruangan dalam memenuhi keperluan penggunanya (pegawai), memiliki fungsi yang dapat disesuaikan dengan kebutuhan pegawai, serta memiliki kemampuan tata letak yang dapat diubah dengan cepat.

Dalam menciptakan tempat kerja yang fleksibel untuk pegawai, tentu perusahaan diharapkan dapat menyediakan segala kebutuhan maupun fasilitas yang dapat menunjang kinerja pegawai. Sejalan dengan hal tersebut, Murray dalam Hassanain (2006) menyebutkan 


\section{EDUCORETAX}

Volume 1 No. 1, Maret 2021

pengembangan tempat kerja yang fleksibel memerlukan penyusunan ulang pada ruangan kantor yang lama. Penyusunan tersebut diperlukan untuk dapat menambah fasilitas yang dapat digunakan oleh pegawai kantor tersebut, seperti misalnya pusat konferensi, ruang makan atau café, ruang pertemuan, dan perpustakaan.

Pengembangan tempat kerja yang fleksibel ini terpengaruh oleh beberapa faktor. Berdasarkan penelitian yang telah dilakukan oleh Hassanain (2006), terdapat delapan belas faktor yang memengaruhi penyediaan tempat kerja yang fleksibel. Delapan belas faktor ini telah dikategorikan kembali menjadi empat faktor, yaitu perencanaan bangunan, tata letak dari tempat kerja fisik, jaringan telekomunikasi dan informasi, serta sistem layanan gedung. Dari keempat faktor tersebut, salah satu faktor yang memiliki dampak langsung pada kinerja dan kenyamanan kerja karyawan adalah tata letak tempat kerja dan fisik. Earle (2003) menyatakan bahwa tidak ada yang dapat meningkatkan kemampuan organisasi untuk mempertahankan pegawainya selain penawaran gaji yang lebih tinggi dan penyediaan lingkungan kerja yang baru dan fleksibel. Sejalan dengan hal tersebut, dalam penelitian yang dilakukan oleh Hassanain (2006) dijelaskan bahwa salah satu hal yang diupayakan dalam penyusunan tata letak kerja dan fisik adalah dengan menerapkan konsep open space.

\section{Open space}

Hedge (1982) menjelaskan bahwa istilah open space mengacu pada penataan ruang kantor yang lebih fleksibel serta tidak ada dinding yang memisahkan, atau pemisah hanya berupa partisi rendah yang memudahkan aktivitas pegawai. Ruang kerja berupa open space meliputi berbagai fasilitas pendukung lain, seperti collaboration space (ruang rapat kecil, ruang rapat besar, dan perangkat pendukung video conference), leisure area (dapur atau ruang bersama), care room, serta area penyimpanan atau loker untuk pegawai (CTO, 2020). Konsep ruang kerja berupa open space diharapkan dapat lebih memberdayakan pegawai, bukan hanya sekadar tempat di mana pegawai wajib berada, tapi juga harus bisa mendukung berbagai aktivitas pegawai.

Selain dapat mendukung aktivitas pegawai, open space juga merupakan bentuk tata ruang kerja yang dapat mendorong pegawai untuk berinteraksi satu sama lain (Allen \& Gerstberger, 1973). Tata ruang kerja yang terbuka dengan cara meminimalisasi partisi memungkinkan adanya komunikasi antarpegawai yang lebih baik agar para pegawai dapat berkolaborasi untuk mencapai kinerja yang optimal, yang tentu akan berdampak pada organisasi (Prabawani \& Sungkar, 2018). Hal tersebut sejalan dengan apa yang disampaikan oleh Kornberger dan Clegg (2004) bahwa tempat kerja memiliki andil untuk membentuk interaksi antarmanusia dan memengaruhi perilaku serta kepuasan dalam bekerja. Hal ini sesuai dengan tujuan dari penerapan open space itu sendiri, yaitu mengubah budaya organisasi sektoral menjadi kolaboratif, di mana para pegawai dapat dengan mudah berinteraksi dan berdiskusi dengan pegawai lain untuk mempermudah penyelesaian pekerjaan (CTO, 2020).

Sebuah studi yang dilakukan oleh Irving (2016) pada tiga organisasi berbeda di Australia menunjukkan bahwa lingkungan kerja dengan layout open space dapat meningkatkan minat para pegawai untuk melakukan kolaborasi dengan pegawai lain, sehingga mereka akan terbantu dalam penyelesaian pekerjaannya. Interaksi adalah hal yang sangat diperlukan untuk menjaga hubungan antarpegawai serta mendorong pegawai untuk dapat bertukar pikiran perihal pekerjaan yang tentu akan berdampak baik pada produktivitas pegawai.

Studi lain juga dilakukan oleh Santoso (2020) pada unit kerja Direktorat Jenderal Pajak, yaitu Direktorat Kepatuhan Internal dan Sumber Daya Aparatur (KITSDA) dan Kantor Pelayanan Pajak (KPP) Pratama Medan Kota. Hasil penelitian tersebut menjelaskan bahwa di unit kerja yang sudah menerapkan open space (yaitu pada salah satu subdirektorat di Direktorat KITSDA), para pegawai merasa lebih nyaman dalam melaksanakan pekerjaan dengan tata ruang kantor yang terbuka. Kenyamanan tersebut memberikan mereka motivasi yang lebih baik 


\section{EDUCORETAX}

Volume 1 No. 2, Juni 2021

dalam bekerja. Motivasi dalam bekerja merupakan suatu hal yang harus dimiliki oleh setiap pegawai, karena semakin tinggi seorang pegawai memiliki motivasi dalam pekerjaannya maka secara tidak langsung akan berdampak positif terhadap peningkatan kinerja pegawai tersebut. Dalam penelitian yang dilakukan, terlihat adanya peningkatan kolaborasi, produktivitas, dan kepuasan kerja pegawai di unit kerja yang telah menerapkan open space.

Dalam penerapannya, open space memiliki kelebihan dibandingkan dengan tata ruang kantor yang lain. Penghilangan sekat antarpegawai membuat ruangan yang ditempati oleh pegawai terkesan lebih luas sehingga akan berpengaruh pada kepuasan pegawai. Marans dan Yan (1998) menjelaskan kepuasan pegawai pada open space salah satunya bergantung pada seberapa luas ruangan kerja yang digunakan oleh pegawai tersebut. Penelitian lain yang dilakukan oleh Thanem, Varlander, dan Cummings (2011) juga menjelaskan kelebihan dari penerapan open space. Berdasarkan hasil penelitian tersebut, open space dapat memberikan kontrol pengawasan antarpegawai, di mana pegawai yang satu dapat mendisiplinkan pegawai yang lain, sehingga akan tercipta lingkungan bekerja yang disiplin dan nyaman bagi pegawai.

Namun, di samping keberhasilan tersebut, open space juga memiliki beberapa kelemahan. Sundstorm, dkk. (1994) dalam penelitiannya menjelaskan penerapan open space memberikan pengaruh negatif kepada pegawai karena sebagian besar dari mereka membutuhkan privasi dan ketenangan untuk melakukan pekerjaannya. Kelemahan yang sama juga dijelaskan oleh Santoso (2020), bahwa kebutuhan ruang privasi bagi pegawai sangat terbatas dan pegawai kesulitan dalam melakukan standardisasi tata ruangan karena terdapat perbedaan di setiap gedung kantor. Subbab berikut akan membahas secara lebih detail hasil penelitian-penelitian terdahulu yang berkaitan dengan penerapan open space di beberapa organisasi, baik sektor swasta maupun pemerintahan.

\section{Penelitian Terdahulu}

Hasil pencarian literatur dengan topik penerapan open space, terutama di Indonesia, menunjukkan bahwa penelitian di bidang ini masih terbatas. Penelitian Santoso (2020) membahas tentang penerapan flexi working space dan flexi working time di Direktorat Jenderal Pajak, dampak dari penerapan flexi working space dan flexi working time, serta tantangan dan risiko yang dihadapi dalam penerapan kebijakan tersebut. Penelitian dilakukan di dua lokus yang berbeda, yaitu Direktorat Kepatuhan Internal dan Transformasi Sumber Daya Aparatur (KITSDA) Direktorat Jenderal Pajak dan Kantor Pelayanan Pajak Pratama Medan Kota.

Hasil penelitian menunjukkan bahwa piloting flexi working space yang telah dilakukan di Direktorat KITSDA mendapat respons positif dari para pegawai. Selain memberikan suasana baru dalam bekerja, open space yang diterapkan secara tidak langsung juga memberi dampak yang baik pada kinerja pegawai di kantor. Namun, di balik respons positif tersebut, terdapat pula tantangan dalam penerapan open space di KITSDA, di antaranya adalah kebutuhan akan ruang pribadi, keberadaan berkas fisik, dan jenis pekerjaan

Penelitian Santoso (2020) juga dilakukan di Kantor Pelayanan Pajak Pratama Medan Kota. Berdasarkan hasil penelitian tersebut diperoleh informasi bahwa Kantor Pelayanan Pajak Pratama Medan Kota belum siap melaksanakan open space karena masih terdapat hal-hal yang menghambat penerapannya, salah satunya banyak berkas fisik yang harus diarsipkan.

Selain penelitian yang dilakukan di organisasi publik, terdapat penelitian lainnya di sektor swasta yang dilakukan oleh Afifah (2019) yang membahas tentang pemanfaatan layout kantor yang efektif bagi perusahaan startup, efisiensi dan efektivitas, serta kelebihan dan kekurangan dan kelebihan dalam penerapannya. Hasil penelitian menunjukkan bahwa layout kantor terbuka merupakan layout kantor yang efektif untuk perusahaan startup karena pegawai dapat memaksimalkan pekerjaan dengan saling berinteraksi, berkoordinasi satu sama lain, saling mengawasi, dan mudah bersosialisasi. Dari segi efisiensi, layout kantor terbuka yang diterapkan oleh perusahaan startup dapat menghemat jumlah biaya yang dikeluarkan dan 


\section{EDUCORETAX}

Volume 1 No. 1, Maret 2021

jumlah ruangan yang diperlukan. Jika dibandingkan dengan penelitian Richard (2020), tampaknya pegawai di organisasi yang diteliti Afifah (2019) memberikan respons yang lebih positif atas penerapan open space.

Penelitian lain juga dilakukan oleh Allen dan Gerstberger (1973) pada sebuah departemen yang diikuti oleh sembilan belas partisipan, yang terdiri dari lima belas orang pegawai dan empat orang insinyur. Dalam penelitian tersebut dijelaskan bahwa penggantian ruangan menjadi ruangan nonteritorial disambut baik oleh pegawai. Hal ini berpengaruh pada peningkatan komunikasi dan koordinasi yang terjadi antarpegawai maupun antara pegawai dengan insinyur dalam departemen tersebut. Respons positif yang ditimbulkan dalam penerapan open space pada penelitian ini sejalan dengan penelitian yang dilakukan oleh Santoso (2020). Kedua penelitian menjelaskan bahwa penerapan open space menyebabkan pegawai menunjukkan peningkatan dalam kinerjanya.

Penulis melakukan penelitian ini untuk melengkapi penelitian-penelitian sebelumnya mengenai penerapan open space. Penelitian yang dilakukan oleh Santoso (2020) di unit kerja Direktorat Jenderal Pajak, yaitu Direktorat KITSDA dan KPP Pratama Medan Kota menjelaskan bahwa dari kedua unit kerja tersebut, open space baru dapat diterapkan di Direktorat KITSDA. KPP Pratama Medan Kota belum menerapkan konsep open space karena beberapa pegawai memandang bahwa belum semua unit di DJP siap untuk menerapkan open space karena kesulitan pegawai untuk mengorganisasikan berkas-berkas fisik, infrastruktur yang belum mendukung penerapan open space, serta jenis pekerjaan dan proses bisnis yang berbeda.

Penerapan open space ini juga tidak menutup kemungkinan untuk dapat menimbulkan respons yang berbeda meskipun diterapkan pada unit kerja yang memiliki kesamaan proses bisnis. Penelitian ini dilakukan untuk mengetahui bagaimana respons pegawai di KPP Pratama Tangerang Timur yang memiliki proses bisnis sama dengan KPP Pratama Medan Kota. Namun, dalam hal ini KPP Pratama Tangerang Timur telah terlebih dahulu menerapkan open space sebagai konsep penataan ruang kantornya.

Penelitian yang dilakukan oleh Afifah (2019) mengulas penerapan open space pada sektor perusahaan start-up swasta. Penelitian tersebut belum secara spesifik memaparkan tantangan yang terjadi dari open space yang diterapkan serta solusinya. Pada penelitian ini, penulis mencoba untuk melengkapi penelitian tersebut dengan mengulas tantangan dan solusi dari penerapan open space..

\section{METODE}

Metode penelitian yang digunakan penulis adalah metode penelitian kualitatif. Penelitian ini dilakukan untuk mengetahui bagaimana penerapan, dampak, tantangan dan solusi dilaksanakannya open space di Kantor Pelayanan Pajak Pratama Tangerang Timur dari sudut pandang pegawai sebagai penerima kebijakan tersebut. Berkaitan dengan hal itu, pengambilan data kualitatif dengan metode wawancara kepada beberapa pegawai di objek penelitian adalah pilihan yang tepat karena dengan metode ini penulis dapat melihat berbagai sudut pandang pegawai mengenai penerapan open space di kantornya.

Penelitian ini menggunakan teknik wawancara dan visual method sebagai metode pengumpulan data. Penulis menggabungkan hasil wawancara dengan informasi lain, yaitu foto atau gambar berupa tata ruang kerja dari setiap seksi yang telah melaksanakan open space serta fasilitas-fasilitas pendukungnya. Data berupa foto dan gambar diperoleh dengan permintaan data kepada objek penelitian secara daring (melalui surat elektronik atau sarana pertukaran data sejenis).

Jenis wawancara yang digunakan dalam penelitian ini adalah semi-structured interview, yaitu jenis wawancara di mana pewawancara menyiapkan pertanyaan kunci sebagai panduan 


\section{EDUCORETAX}

Volume 1 No. 2, Juni 2021

sebelum dilakukan wawancara dengan partisipan (Saunders, Lewis, \& Thornhill, 2019). Narasumber yang menjadi partisipan dalam penelitian ini dipilih menggunakan purposive sampling, yaitu sampel yang dipilih secara cermat sehingga relevan dengan penelitian (Nasution, 1995). Kriteria yang ditentukan dalam menentukan sampel untuk wawancara adalah pegawai di KPP Pratama Tangerang Timur berdasarkan jabatan, yaitu pelaksana, account representative, fungsional, kepala seksi, dan kepala kantor. Pengumpulan data dilakukan secara one-to-one interview melalui media telepon atau secara daring karena keterbatasan pembatasan sosial akibat pandemi.

Setelah dilakukan proses pengumpulan data melalui wawancara, seluruh data berupa transkrip wawancara diolah dengan menggunakan teknik coding, yaitu proses menguji dan menelaah data yang ada dengan memberikan label dalam bentuk kata, frase, atau kalimat (Junaid, 2016). Penulis melakukan coding secara deduktif yaitu coding dilakukan dengan data top-down yang berarti sebelum melakukan penelitian peneliti telah menentukan teori atau analisis minat sesuai keadaan di lapangan (Boyatzis, 1998). Sejalan dengan hal tersebut, dalam melakukan olah data, penulis terlebih dahulu menentukan code atau label berdasarkan tujuan penelitian. Seluruh transkrip wawancara kemudian dilakukan coding dengan memberikan code pada setiap jawaban partisipan yang sesuai dengan satu atau lebih masalah penelitian yang sesuai. Contoh pengkodingan transkrip wawancara dan daftar kode dapat dilihat pada Lampiran 2. Hasil pengolahan data akan disajikan setelah pembahasan mengenai gambaran umum objek penelitian.

\section{HASIL DAN PEMBAHASAN Hasil Penelitian}

Penerapan konsep open space yang dilakukan oleh Kantor Pelayanan Pajak Pratama Tangerang Timur sejak tahun 2018 tentu memberikan dampak kepada pegawainya, baik dampak positif maupun negatif. Selain itu, pegawai juga merasakan beberapa tantangan akibat dari penerapan konsep open space dan menemukan solusi atas tantangan tersebut. Hasil wawancara dengan partisipan mengenai penerapan, dampak, tantangan, dan solusi dari konsep open space tertuang dalam pembahasan hasil berikut:

\section{Penerapan Open space}

\section{Kondisi Sebelum Penerapan Open space}

Sebelum tahun 2018, Kantor Pelayanan Pajak Pratama Tangerang Timur masih menerapkan tata ruang kantor tertutup dengan menggunakan sekat atau cubicle untuk memisahkan setiap meja kerja karyawan. Hasil pengolahan data wawancara menunjukkan bahwa terdapat beberapa isu berkaitan dengan tata ruang kantor tertutup atau bersekat, antara lain masalah fleksibilitas ruang kerja, ketidaknyaman, dan ketidakamanan yang akan dijelaskan pada paragraf berikut.

Sebelum penerapan open space, kantor ini menggunakan jenis tata ruangan kantor dengan design yang tertutup, yaitu bentuk kantor dengan ruangan yang dipisah atau dibagi dalam kamar ruang kerja (cubicle) tersendiri untuk setiap karyawannya (Sedarmayanti, 2009). Berdasarkan hasil wawancara, bentuk tata ruang kantor sebelum open space ini memiliki beberapa kelemahan. Kelemahan pertama adalah ruangan yang tidak terlalu fleksibel untuk dilakukan perubahan apabila terdapat suatu hal yang mendesak, seperti mutasi pegawai.

Dulu pegawai nambah 2 cuma yang keluar cuma 1 misalnya gitu ya itu kan mejanya kurang jadinya satu cubicle berdua, waktu itu saya ingat satu cubicle dibuat berdua jadi satu hadap sana satu hadap sini, sempit banget gitu kan ya jadi ngerasain sempitnya.

Hal ini sejalan dengan konsep yang disampaikan oleh Sedarmayanti (2009) bahwa salah satu kelemahan dari penerapan bentuk tata ruang kantor tertutup ini adalah pemakaian ruangan 


\section{EDUCORETAX}

Volume 1 No. 1, Maret 2021

yang kurang luwes apabila terdapat perubahan atau perkembangan dalam suatu organisasi. Hal ini dapat membuat pegawai merasa kurang nyaman bekerja dengan kondisi tersebut.

Selain rasa tidak nyaman akibat ruang kerja yang tidak fleksibel, pegawai juga merasa tidak nyaman karena segala kegiatan yang dilakukannya dapat dilihat secara langsung oleh Wajib Pajak. Hal ini membuat pegawai tidak leluasa untuk melakukan kegiatan di meja kerjanya, baik itu yang berhubungan dengan pekerjaan maupun kegiatan lainnya.

Kelemahan lain adalah pegawai merasa tidak aman karena akses Wajib Pajak yang masih bebas untuk keluar masuk ruangan. Sebelum diterapkannya open space, pelayanan kepada Wajib Pajak sebagian besar dilakukan di meja kerja pegawai. Hal ini membuat Wajib Pajak dapat bebas hilir mudik di ruangan sehingga mengganggu privasi pegawai.

Di waskon 1 itu dulu kami melayani Wajib Pajak itu di ruangan, bener-bener di ruangan kerja kami, jadi nanti di ruangan kerja dengan cubicle segitu banyak dan meja yang dipepet-pepetin lah ya untuk dapat memuat Wajib Pajak itu, itu ekstrim kalau dibandingkan seksi lain. Jadi terus Wajib Pajak hilir mudik masuk keluar ruangan jadi intinya banyak orang tidak dikenal keluar masuk kan ya, jadi prinsipnya tidak aman. Kedua tidak nyaman gitu kan karena kita bolak balik ke kamar mandi kelihatan Wajib Pajak gitu kan ya, habis makan masih belepotan gitu kan gak enak ya, terus kami juga ngelayanin sepanjang hari di ruangan yang kelihatan temen-temen lain, tidak enak dan gak sreg aja. (kutipan wawancara dari pegawai Kantor Pelayanan Pajak Pratama Tangerang Timur)

Kurangnya fleksibilitas ruang kantor, ketidaknyamanan, dan ketidakamanan pegawai merupakan beberapa dampak yang ditimbulkan dari desain ruangan terbuka. Hal itu mendorong instansi, dalam hal ini adalah Kementerian Keuangan, untuk membuat suatu kebijakan guna mengatasi permasalahan tersebut.

\section{Open space: bagian dari program New Ways of Working}

Terobosan demi terobosan dilakukan oleh Kementerian Keuangan demi menjawab setiap permasalahan yang terjadi, salah satunya mengenai desain tata ruang kantor. Salah satu tema sentral dalam Keputusan Menteri Keuangan Nomor 302/KMK.01/2019 yang telah diperbarui dengan Keputusan Menteri Keuangan Nomor 91/KMK.01/2021 tentang Implementasi Inisiatif Strategis Program Reformasi Birokrasi dan Transformasi Kelembagaan Kementerian Keuangan adalah Penguatan Budaya Kementerian Keuangan: New Ways of Working. Terobosan yang akan dilakukan oleh Kementerian Keuangan dalam rangka memberikan dorongan untuk perubahan mindset, pola kerja, dan semangat pelaksanaan tugas dalam menghadapi transformasi digital dan tren perubahan mekanisme kerja.

Terdapat delapan belas terobosan yang telah dilakukan sejak tahun 2019 hingga tahun 2021. Pada tahun 2021, dalam milestone disebutkan bahwa ada empat terobosan yang akan dilakukan, yaitu (1) Tata kelola implementasi FWS (flexible working space); (2) Fleksibilitas waktu bekerja (FWH); (3) Implementasi Activity Based Working (ABW) kantor pusat dan daerah; dan(4) Piloting implementasi dan penyusunan RKMK integrity framework.

Salah satu terobosan dalam ketentuan tersebut yang sejalan dengan penelitian ini adalah program Activity Based Workplace yang mencakup penerapan open space. Penerapan ini tidak hanya dilakukan di lingkup kantor Kementerian Keuangan, tetapi juga di seluruh Unit Eselon 1 Kementerian Keuangan, termasuk Direktorat Jenderal Pajak (DJP).

Konsep open space mulai diperkenalkan oleh Kementerian Keuangan pada tahun 2019 melalui program Inisiatif Strategis Reformasi Birokrasi dan Transformasi Kelembagaan (IS RBTK). Namun, sebelum itu, terdapat beberapa kantor yang telah menerapkan konsep open space ini. Salah satu unit kerja dalam lingkup Direktorat Jenderal Pajak yang telah menerapkan open space adalah Kantor Pelayanan Pajak Pratama Tangerang Timur.

Tahapan dan Konsep Penerapan Open space

Page / 163 


\section{EDUCORETAX}

Volume 1 No. 2, Juni 2021

Kantor Pelayanan Pajak Pratama Tangerang Timur telah menerapkan konsep open space sebagai bentuk penataan ruang kantornya sejak tahun 2018. Proses transisi perubahan tata ruang kerja dari konsep closed space atau qubicle menjadi open space berlangsung selama 3-6 bulan. Jangka waktu tersebut mencakup segala persiapan untuk menerapkan open space dengan langkah-langkah seperti diilustrasikan pada Gambar 1.

Gambar 1 Tahapan Penerapan Open space

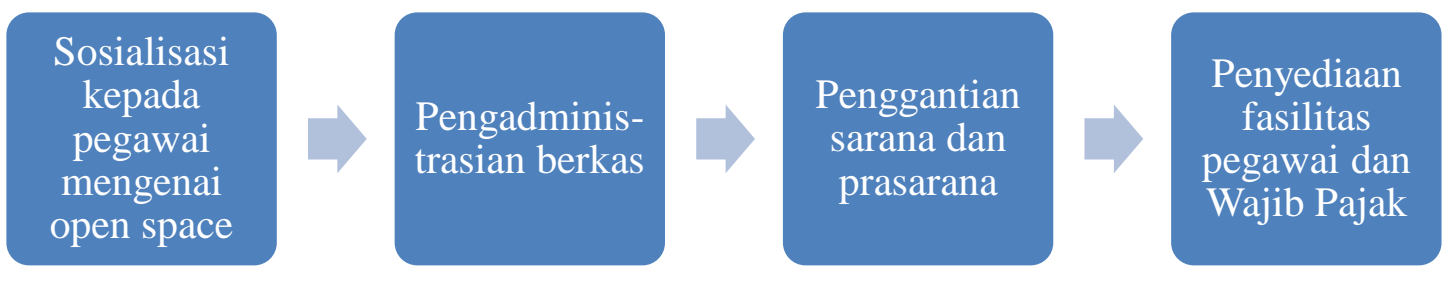

Sumber: Diolah oleh penulis dari data wawancara

Langkah pertama yang dilakukan adalah sosialisasi mengenai penerapan open space kepada seluruh pegawai. Setelah sosialisasi dilakukan, langkah selanjutnya adalah pengadministrasian berkas. Seluruh berkas dilakukan scan kemudian di-input ke dalam aplikasi Sinar Tangtim, yaitu aplikasi yang digunakan untuk menyimpan seluruh berkas yang terkait dengan pekerjaan pegawai Kantor Pelayanan Pajak Pratama Tangerang Timur.

Jadi sebelum open space persiapannya itu kita merapikan semua berkas dulu kan buat diadministrasikan. Semua berkas diarsipkan dulu, terus dipindahkan, terus cubicle baru dicabut, nah setelah itu baru mulai open space. Kalau untuk digitalisasi berkas waktu awal awal ada masa transisi kita kan melakukan pemberkasaan, jadi berkas berkas yang ada di meja itu di kardusin terus masukin ke ruang berkas untuk di digitalisasi, di scan dan di input, nah tapi sekarang kan udah ada Nadine kan jadi ya makin bersih lagi, tapi proses administrasi berkasnya pun masih berjalan sampai sekarang. Di Tangerang Timur ada namanya "Sinar Tangtim". (kutipan wawancara dari pegawai Kantor Pelayanan Pajak Pratama Tangerang Timur)

Setelah seluruh berkas diadministrasikan, proses transisi perubahan tata ruang kerja dari konsep closed space atau cubicle menjadi open space berlangsung selama 3-6 bulan dilanjutkan dengan penataan ruangan dan penggantian sarana dan prasarana kantor. Pada tahap ini, Seluruh meja kerja pegawai yang semula berupa cubicle diganti dengan satu meja besar sebagai meja kerja bersama tanpa adanya pembatas atau sekat antarpegawai.

Setelah penggantian sarana dan prasarana, Kantor Pelayanan Pajak Pratama Tangerang Timur mulai membuat dan menambah fasilitas-fasilitas penunjang open space untuk pegawai dan Wajib Pajak. Kantor Pelayanan Pajak Pratama Tangerang Timur menyediakan laptop sebagai pengganti komputer yang dapat digunakan oleh beberapa pegawai untuk menunjang kinerjanya. Selain itu, terdapat fasilitas-fasilitas lain yang disediakan untuk mendukung kegiatan pegawai selama berada di kantor antara lain: (a) pantry yang dapat digunakan pegawai untuk makan, memasak, dan menyimpan persediaan makanan; (b) loker yang digunakan untuk menyimpan barang pribadi milik pegawai; (c) tempat untuk olahraga (mini gym, mini biliar, panahan); (d) lounge yang dapat digunakan pegawai untuk melakukan pekerjaannya atau melakukan brainstorming dengan pegawai lain; dan (e) ruangan yang disediakan bagi pegawai untuk beristirahat.

Konsep open space yang diterapkan di Kantor Pelayanan Pajak Pratama Tangerang Timur ini telah sesuai dengan kriteria yang dijelaskan oleh CTO (2020). Ruang kerja berupa open space meliputi berbagai fasilitas pendukung lain, seperti collaboration space (ruang rapat kecil, ruang rapat besar, dan perangkat pendukung video conference), leisure area (dapur atau ruang bersama), care room, serta area penyimpanan atau loker untuk pegawai. 


\section{EDUCORETAX}

Volume 1 No. 1, Maret 2021

Selain fasilitas yang disediakan bagi pegawai, fasilitas open space juga disediakan untuk Wajib Pajak. Kantor Pelayanan Pajak Pratama Tangerang Timur telah melakukan penataan pada lantai satu gedung kantor untuk dijadikan space khusus Wajib Pajak. Fasilitasfasilitas yang disediakan untuk Wajib Pajak antara lain adalah ruang layanan mandiri. Di dalam ruangan ini terdapat laptop dan komputer yang dapat digunakan Wajib Pajak untuk menjalankan kewajiban perpajakannya. Fasilitas lain yang juga disediakan adalah lounge Wajib Pajak yang dapat digunakan untuk Wajib Pajak bertemu dengan Account Representative atau melakukan pembahasan dengan pemeriksa pajak, atau hal-hal lain yang terkait dengan pemenuhan kewajiban perpajakannya.

Jika dibandingkan dengan ketentuan, terdapat satu hal yang berbeda dalam penerapan konsep open space yang dilakukan oleh Kantor Pelayanan Pajak Pratama Tangerang Timur, yaitu pegawai hanya menempati satu tempat yang tidak berubah setiap harinya. Hal ini sedikit berbeda dengan penerapan open space yang diatur dalam Keputusan Menteri Keuangan Nomor 91/KMK.01/2021 tentang Implementasi Inisiatif Strategis Program Reformasi Birokrasi dan Transformasi Kelembagaan Kementerian Keuangan. Pada peraturan ini dijelaskan bahwa pegawai tidak berhak memonopoli okupansi area tertentu dalam rangka melaksanakan pekerjaannya sehingga pegawai seharusnya bisa berpindah tempat duduk di manapun dia ingin mengerjakan pekerjaannya.

Berdasarkan wawancara yang dilakukan dengan partisipan, seluruh partisipan berpendapat bahwa penerapan open space di Kantor Pelayanan Pajak Pratama Tangerang Timur sudah sesuai dengan ekspektasi mereka terkait open space. Pegawai membayangkan open space sebagai ruangan kerja yang terbuka dengan beberapa meja besar yang digunakan untuk bekerja bersama-sama dengan pegawai lain dan dilengkapi dengan beberapa fasilitas pendukung seperti loker, ruangan untuk istirahat, dan ruang rapat.

Konsep penerapan open space yang diterapkan KPP Pratama Tangerang Timur sejalan dengan penelitian yang dilakukan oleh Irving (2016) bahwa karyawan di Gedung Sains Australia yang telah menerapkan open space cenderung lebih kolaboratif saat melakukan pekerjaannya. Hal tersebut terjadi karena penerapan open space memberikan fasilitas lebih kepada mereka untuk melakukan kolaborasi. Selain itu, karyawan juga menganggap bahwa kantor dengan konsep open space memberikan kemudahan berinteraksi dengan yang lain.

Berdasarkan wawancara yang telah dilakukan dengan partisipan, seluruh partisipan berpendapat bahwa penerapan open space di Kantor Pelayanan Pajak Pratama Tangerang Timur sudah sesuai dengan ekspektasi mereka terkait open space. Pegawai membayangkan open space sebagai ruangan kerja yang terbuka dengan beberapa meja besar yang digunakan untuk bekerja bersama-sama dengan pegawai lain dan dilengkapi oleh beberapa fasilitas pendukung seperti loker, ruangan untuk istirahat, dan ruang rapat. Narasumber mengungkapkan, "Udah sih, kayaknya udah memenuhi semua bayangan saya tentang open space" (kutipan wawancara dari pegawai Kantor Pelayanan Pajak Pratama Tangerang Timur).

Ekspektasi pegawai mengenai open space telah terwujudkan dengan penerapan open space di Kantor Pelayanan Pajak Pratama Tangerang Timur. Seluruh sekat antarpegawai dan antarseksi dihilangkan, penggunaan meja besar sebagai tempat kerja untuk pegawai, penambahan fasilitas-fasilitas yang diperlukan oleh pegawai maupun Wajib Pajak dan perubahan-perubahan lain terkait open space direspons secara baik oleh pegawai.

Oke kalau menurut saya open space berjalan lancar cuman yang namanya adaptasi kan terus berlangsung, kalau dari yang kami rasain di sini pun dampaknya lebih banyak yang positif dari pada yang negatifnya. (kutipan wawancara dari pegawai Kantor Pelayanan Pajak Pratama Tangerang Timur)

Konsep open space yang diterapkan di Kantor Pelayanan Pajak Pratama Tangerang Timur sebagian besar telah sesuai dengan kriteria yang diberikan oleh Central Transformation 


\section{EDUCORETAX}

Volume 1 No. 2, Juni 2021

Office (CTO) dan juga telah memenuhi ekspektasi pegawai. Penerapan ini memberikan perubahan pada lingkungan kerja pegawai, dari yang semula menggunakan tata ruang kantor tertutup kemudian diubah menjadi tata ruang kantor terbuka. Perubahan tersebut tentu akan menimbulkan dampak bagi pegawai, baik dampak positif maupun negatif. Penjelasan mengenai dampak dari penerapan open space tersebut akan dibahas pada bagian berikutnya.

\section{Dampak Penerapan Open space}

Open space sebagai hal yang baru bagi pegawai Kantor Pelayanan Pajak Tangerang Timur memberikan dampak positif dan negatif yang dirasakan oleh pegawai. Dampak positif dan negatif tersebut akan dibahas pada bagian ini.

\section{Dampak Positif Penerapan Open space}

Berdasarkan hasil pengolahan data wawancara, penulis mengidentifikasi beberapa dampak positif dari penerapan open space di Kantor Pelayanan Pajak Pratama Tangerang Timur. Dampak positif tersebut di antaranya adalah meningkatkan komunikasi dan koordinasi, memudahkan pengawasan, space kerja lebih luas, serta clean space dan zero waste.

a. Meningkatkan komunikasi dan koordinasi

Penerapan open space berupa tata ruang kantor tanpa pembatas atau sekat memiliki dampak positif, yaitu meningkatkan komunikasi dan koordinasi antarpegawai maupun pegawai dengan atasannya. Pegawai dapat melakukan interaksi maupun diskusi dengan pegawai lain tanpa harus mendatangi cubicle pegawai yang bersangkutan sehingga akan menghemat waktu dan pekerjaan akan selesai dengan lebih efisien. Sebagaimana disampaikan oleh pegawai W (seorang account representative), open space memberikan kemudahan untuk dapat berinteraksi dengan pegawai yang lain sehingga memberikan keleluasaan untuk dapat melakukan koordinasi terkait pekerjaan. Hilangnya sekat atau pembatas juga membuat pegawai menjadi lebih akrab satu sama lain. Hal ini disebabkan karena pegawai lebih leluasa melakukan interaksi dengan pegawai lain.

Sekarang enak banget jadi kita koordinasi dengan seksi lain pun lancar gitu. karena saking terbukanya ya kita lebih akrab jadinya, lebih banyak bercanda, koordinasi pas kerja jadi enak banget kalau sekarang. Sekarang langsung bisa ngumpul, kepala seksi "ayo kita rapat!” ya udah tinggal narik kursi ke kepala seksi kan gak ada kubikel juga jadi tinggal ngumpul aja di sekitar mejanya terus kita ngobrol diskusi jadi lebih enak banget koordinasinya lebih lancar. (kutipan wawancara dari pegawai Kantor Pelayanan Pajak Pratama Tangerang Timur)

Peningkatan dalam komunikasi ini juga dijelaskan dalam penelitian yang dilakukan oleh Allen dan Gerstberger (1973). Komunikasi pada departemen di mana percobaan dilakukan mengalami kenaikan signifikan dengan adanya skema penataan ruang yang baru (nonterritorial office). Dengan adanya peningkatan komunikasi tersebut maka terjadi peningkatan koordinasi.

Selain kemudahan dalam melakukan interaksi dengan pegawai lain, kemudahan dalam melakukan diskusi dengan atasan juga menjadi kelebihan dalam penerapan open space ini. Hilangnya sekat antara ruangan pegawai dengan ruangan atasan membuat diskusi dapat dilakukan di tempat yang sama serta di waktu yang sama tanpa harus melewati sekat antara ruangan pegawai dan ruangan atasan. Hal ini diharapkan akan memberikan dampak yang baik bagi produktivitas pegawai.

b. Memudahkan pengawasan

Ruangan kerja yang disusun dengan menghilangkan sekat atau pembatas dan hanya menggunakan satu meja besar yang diisi oleh beberapa pegawai tentu akan memberikan akses lebih kepada pegawai agar dapat melihat satu sama lain. Hal ini akan memberi kemudahan bagi pegawai maupun atasan dalam melakukan pengawasan terhadap pegawai lainnya.

Hasil pengolahan data wawancara menunjukkan bahwa penerapan open space memudahkan pengawasan, khususnya berkaitan dengan pemantauan kode etik dan disiplin 


\section{EDUCORETAX}

Volume 1 No. 1, Maret 2021

pegawai. Secara ketentuan, berdasarkan Keputusan Menteri Keuangan Nomor 91/KMK.01/2021 tentang Organisasi dan Tata Kerja Instansi Vertikal Direktorat Jenderal Pajak, pemantauan pengendalian intern kantor dan pemantauan terhadap kode etik dan disiplin merupakan tugas Subbagian Umum dan Kepatuhan Internal. Namun, dengan adanya open space, setiap pegawai dapat menjadi pengawas bagi pegawai yang lain. Dengan demikian, pengawasan atas penegakan etika dan disiplin pegawai dilakukan secara bersama-sama oleh para pegawai, tidak hanya dilakukan oleh Subbagian Umum dan Kepatuhan Internal.

Dampak untuk pekerjaan seperti yang saya bilang kalau misalnya open space kan antar pegawai satu sama lain saling mengawasi, kalau unit kepatuhan internal kan tugasnya mengawasi pegawai kan, nah dengan adanya open space otomatis beban untuk mengawasi akan tersebar gitu, tidak perlu saya doang yang mengawasi antar teman juga pun mengawasi, kalau misalnya sebelum open space kan kita gak bisa 24 jam mengawasi tapi kalau teman kerja sebelahnya pasti melihat terus dong dari pagi sampai sore. (kutipan wawancara dari pegawai Kantor Pelayanan Pajak Pratama Tangerang Timur)

Kemudahan pengawasan ini sesuai dengan hasil penelitian yang dilakukan oleh Thanem, Varlander, \& Cummings (2011) bahwa penerapan open space dapat secara otomatis memberikan kontrol pengawasan antarpegawai, di mana pegawai yang satu dapat mendisiplinkan pegawai lain maupun antara atasan dengan pegawai di bawahnya.

Selain memberikan kemudahan untuk melakukan pengawasan antarpegawai, penerapan open space juga memberikan kemudahan dalam melakukan pengawasan atas interaksi yang dilakukan antara pegawai dan Wajib Pajak. Hal ini dilakukan untuk menghindari adanya gratifikasi maupun hal-hal lain yang merugikan pegawai serta Wajib Pajak.

Intinya lebih nyaman lah ya, ngawasinnya gampang karena hampir semua ruangan ada cetv dan cctv-nya juga memantau semua jadi untuk menghindari gratifikasi kah tau apa ya, mengawasilah prinsipnya mengawasi pegawai apakah benar bekerja tau ternyata maen kan kelihatan jadi menguntungkan semua pihak sih sebenernya gitu saling menjaga. Karena dengan open space kemungkinan wajib pajak merayu pegawai pajak itu kecil karena semua kelihatan semua kedengeran jadi hampir gak mungkin. (kutipan wawancara dari pegawai Kantor Pelayanan Pajak Pratama Tangerang Timur)

c. Space kerja lebih luas

Dalam wawancara yang dilakukan, salah satu pegawai menyebutkan bahwa penerapan open space memberikan kesan luas pada ruangan kantor. Hal ini disebabkan karena seluruh cubicle telah dihilangkan dan diganti dengan meja besar yang dapat digunakan oleh beberapa orang sekaligus. Seluruh sekat antarseksi juga telah dihilangkan sehingga menambah kesan lebih luas pada ruangan tersebut. Selain itu, penghilangan sekat ini menjadikan ruangan juga lebih rapi dan nyaman.

Ruangan emang kelihatan rapi dan luas gak banyak sekat ya, kalau dulu kan banyak sekat ya kayak kubikel-kubikel gitu kan dan jalannya sempit, banyak nyamuk lah yang semut lah sekarang bersih gitulah jadi nyaman. (kutipan wawancara dari pegawai Kantor Pelayanan Pajak Pratama Tangerang Timur)

Selain penghilangan sekat dan penggantian cubicle dengan meja besar, space yang terkesan lebih luas ini juga didukung ketersediaan ruang tersendiri untuk menyimpan berkas Wajib Pajak. Keberadaan ruangan ini diperlukan untuk menyimpan seluruh berkas yang dipinjam dari Wajib Pajak oleh Petugas Fungsional Pemeriksa Pajak untuk melakukan pemeriksaan terkait kepatuhan wajib pajak dan pemeriksaan tujuan lain. Penyediaan ruangan yang digunakan untuk menyimpan segala berkas milik Wajib Pajak ini sejalan dengan penelitian yang dilakukan oleh Marans dan Yan (1989) bahwa kepuasan pegawai pada open space yang diterapkan bergantung pada seberapa luas ruangan kerja dan keberadaan ruangan khusus berupa ruang penyimpanan yang memadai. 


\section{EDUCORETAX}

Volume 1 No. 2, Juni 2021

\section{d. Zero waste dan clean space}

Salah satu prinsip penerapan open space di Kantor Pelayanan Pajak Pratama Tangerang Timur adalah clean space, di mana pegawai harus mengutamakan kebersihan dan kerapian ruang kerja. Kebijakan ini membuat para pegawai harus memastikan meja kerja mereka bebas dari segala macam barang pribadi maupun barang kantor yang memang tidak diperlukan. Konsep open space yang menggunakan meja besar sebagai meja kerja untuk beberapa pegawai sekaligus membuat pegawai tidak dapat meletakkan terlalu banyak barang, selain barang yang memang berhubungan dengan pekerjaan. Dengan diterapkannya clean space ini diharapkan dapat meminimalisasi distraksi yang ada di meja kerja sehingga pegawai dapat lebih fokus dalam melaksanakan pekerjaannya. Selain itu keadaan meja kerja dan ruangan kerja yang bersih diharapkan juga dapat meningkatkan kenyamanan pegawai dalam bekerja sehingga akan berdampak baik pada kinerjanya.

Dan juga prinsipnya open space waktu itu dari Kepala Kantor kan dia gak mau ada dokumen yang terlihat, jadi bener-bener ruang kerja itu clean. (kutipan wawancara dari pegawai Kantor Pelayanan Pajak Pratama Tangerang Timur)

Untuk meminimalisasi peletakan barang di atas meja kerja, Kantor Pelayanan Pajak Pratama Tangerang Timur telah menyediakan loker yang disesuaikan dengan jumlah pegawai sehingga pegawai dapat menyimpan seluruh barang pribadi pada tempat penyimpanan tersebut. Untuk penyimpanan barang yang berhubungan dengan pekerjaan, dalam hal ini adalah berkasberkas, selain berkas Wajib Pajak, yang berbentuk fisik atau hardcopy, Kantor Pelayanan Pajak Pratama Tangerang Timur juga telah menyediakan aplikasi Sinar Tangtim, yaitu aplikasi yang dapat digunakan untuk menyimpan seluruh berkas yang berhubungan dengan pekerjaan pegawai dalam bentuk softcopy.

Semua berkas kami kumpulkan di lantai 2 untuk hardcopy-nya ya, jadi sisanya kami hanya punya $p d f$ jadi kalau kami cari gampang tinggal cari $p d f$ saja terus cetak ulang gitu, terus misal kayak dokumen aslinya kami akan ke lantai 2 koordinasi dengan Subbag Umum dan Kepatuhan Internal untuk nyari dokumen hardcopy-nya gitu, jadi ada aplikasi "Sinar Tangtim". (kutipan wawancara dari pegawai Kantor Pelayanan Pajak Pratama Tangerang Timur)

Adanya aplikasi penyimpanan berkas tersebut membantu penerapan konsep zero waste. Pegawai tidak lagi memerlukan berkas dalam bentuk kertas (selain berkas Wajib Pajak) sehingga dapat meminimalisasi adanya sampah di ruangan kerja. Selain itu, aplikasi juga memudahkan pegawai apabila ingin mencari berkas yang diperlukan.

\section{Dampak Negatif Penerapan Open space}

Selain dampak positif, penerapan open space juga dinilai memberikan dampak negatif bagi sebagian pegawai. Salah satu dampak negatif yang dirasakan oleh sebagian pegawai ini adalah space, dalam hal ini adalah meja kerja, yang lebih kecil atau sempit.

Dengan konsep open space ini kan sebetulnya jadinya meja cenderung lebih sempit ya.

(kutipan wawancara dari pegawai Kantor Pelayanan Pajak Pratama Tangerang Timur)

Penggantian qubicle untuk setiap pegawai dengan satu meja besar yang digunakan bersama mengharuskan para pegawai untuk berbagi satu meja kerja dengan beberapa pegawai lain. Hal ini membuat pegawai merasa tidak leluasa untuk melakukan pekerjaannya. Selain itu juga batasan wilayah kerja antarpegawai menjadi tidak teratur. Hal ini membuat pegawai merasa kesulitan untuk menempatkan barang atau berkas yang berhubungan dengan pekerjaan.

Kalau yang saya rasakan itu meja kerjanya jadi lebih sempit ya, katakanlah ini meja panjang 2,5 meter dibagi untuk 2 orang, sedangkan kami setiap hari harus ubek-ubek dokumen lah, jadi harus bersisian juga sama meja sebelah ee sama teman semeja sekarang kalau dibilang kan. Jadi ya itu, kendalanya adalah space-nya yang makin sempit. (kutipan wawancara dari pegawai Kantor Pelayanan Pajak Pratama Tangerang Timur) 


\section{EDUCORETAX}

Volume 1 No. 1, Maret 2021

Space kerja yang lebih kecil ini paling dirasakan oleh Petugas Fungsional Pemeriksa Pajak. Hal ini disebabkan banyaknya berkas Wajib Pajak yang harus diperiksa sehingga mereka membutuhkan space yang memadai. Meskipun sudah terdapat ruang penyimpanan untuk berkas Wajib Pajak, adakalanya Petugas Fungsional Pemeriksa Pajak harus menaruh banyak berkas Wajib Pajak di meja kerjanya untuk dilakukan pemeriksaan pada waktu yang bersamaan.

Nah dokumennya sendiri kadang kalau wajib pajaknya besar kami bisa sampai dapet sekitar 40 sampai 30 dus ada juga yang 10 atau bisa juga cuma 5. Nah itukan kalau fungsional dalam 1 kantor katakanlah ada 20 termasuk supervisor mau nggak mau kami juga butuh space yang besar untuk menaruh dokumen Wajib Pajak yang kami periksa gitu. (kutipan wawancara dari pegawai Kantor Pelayanan Pajak Pratama Tangerang Timur)

Jika temuan tersebut dibandingkan dengan penjelasan pada subbab sebelumnya, terdapat perbedaan pandangan pegawai mengenai pengertian space dalam penerapan open space ini. Pendapat yang pertama adalah space yang berarti ruangan untuk bekerja atau luas lantai. Pegawai yang memandang space sebagai ruangan kerja beranggapan bahwa open space membuat ruang kerja menjadi terkesan lebih luas. Pendapat kedua adalah space yang berarti luas meja kerja untuk setiap pegawai. Pegawai dalam kelompok ini menganggap penerapan open space justru membuat space atau meja kerja mereka menjadi lebih sempit.

Perbedaan pandangan ini bisa jadi disebabkan karena perbedaan latar belakang pegawai yang menjadi narasumber penelitian ini. Misalnya, sebagaimana dijelaskan pada paragraf sebelumnya, dampak berupa space yang bertambah sempat paling dirasakan oleh pemeriksa pajak. Hal ini berkaitan dengan karakter pekerjaan pemeriksa pajak yang masih memerlukan pemeriksaan fisik atas berkas Wajib Pajak sehingga keberadaan meja kerja dengan luas yang memadai menjadi hal yang penting. Perbedaan pandangan tersebut memperkaya hasil penelitian ini dari sudut pandang yang berbeda.

\section{Tantangan dan Solusi Penerapan Open space}

Penerapan kebijakan baru pada suatu organisasi tentu akan memberikan tantangan tersendiri untuk anggota organisasi tersebut. Sama halnya dengan Kantor Pelayanan Pajak Tangerang Timur, penerapan open space memberikan tantangan tersendiri bagi pegawainya. Tantangan tersebut di antaranya adalah keterbatasan privasi, meningkatnya distraksi atau gangguan, dan perselisihan antar pegawai.

\section{a. Privasi terbatas}

Menurut wawancara yang telah dilakukan, salah satu tantangan yang dirasakan oleh pegawai adalah privasi yang terbatas. Sebelum open space diterapkan, setiap pegawai memiliki cubicle sendiri untuk melakukan segala aktivitas, baik yang terkait dengan pekerjaan maupun aktivitas lainnya. Cubicle memberikan ruang privasi tersendiri untuk pegawai sehingga pegawai tidak merasa sungkan atau merasa mengganggu pegawai yang lain.

Nah privasi agak sedikit berkurang, paling cuma antarpegawai saja privasi masingmasing, misalnya kan kalau di cubicle kan kita kadang banyak nempel foto di cubiclenya gitu-gitu kan, tapi kalau misalnya open space kan gak bisa dan gak enak juga. (kutipan wawancara dari pegawai Kantor Pelayanan Pajak Pratama Tangerang Timur)

Penerapan open space yang mengharuskan cubicle diganti dengan meja besar tanpa sekat membuat pegawai merasa privasinya berkurang. Hal ini sejalan dengan penelitian yang dilakukan oleh Sundstrom, dkk. (1994), di mana penerapan open space memberikan pengaruh negatif kepada pegawai karena sebagian besar dari mereka membutuhkan privasi dan ketenangan untuk melakukan pekerjaannya. Penelitian tersebut juga menjelaskan bahwa pegawai lebih memilih untuk mendapatkan privasi untuk diri mereka daripada peningkatan aksesibilitas di kantor yang disebabkan karena penerapan dari open space. 


\section{EDUCORETAX}

Volume 1 No. 2, Juni 2021

Keterbatasan privasi yang dialami oleh pegawai ini menjadi salah satu alasan disediakannya ruangan istirahat atau ruang ngobrol yang dapat digunakan pegawai untuk melakukan aktivitas yang tidak bisa dilakukan di meja kerjanya karena terlalu terbuka.

b. Meningkatnya distraksi atau gangguan

Tantangan lain yang dialami oleh hampir seluruh partisipan wawancara adalah adanya distraksi atau gangguan akibat penerapan open space di Kantor Pelayanan Pajak Pratama Tangerang Timur. Hilangnya sekat antarpegawai membuat segala hal yang dilakukan oleh seorang pegawai dapat terlihat dan terdengar oleh pegawai lain di dalam ruangan tersebut. Berdasarkan hasil pengolahan data wawancara, beberapa hal yang menyebabkan terbentuknya distraksi yang dirasakan oleh para pegawai adalah suara, musik, telepon maupun suara (noise) lain yang berasal dari pegawai lainnya. Misalnya ada pegawai yang suka setel musik, ada juga kan pegawai yang tidak suka setel musik, nah itu kan agak beda ya. (kutipan wawancara dari pegawai Kantor Pelayanan Pajak Pratama Tangerang Timur). Selain itu, aktivitas seorang pegawai yang dapat secara jelas dilihat oleh temannya juga dapat menjadi salah satu gangguan yang dikhawatirkan dapat berpengaruh pada kinerja pegawai.

Beragam distraksi yang ada membuat pegawai harus melakukan adaptasi dengan berbagai cara. Salah satu cara untuk beradaptasi adalah dengan menyediakan headphone. Di satu sisi, hal ini bisa meminimalisasi suara yang keluar sehingga tidak mengganggu pegawai di sekitarnya. Di sisi lain, cara tersebut juga sekaligus bisa mengurangi gangguan suara dari luar.

Sekarang kan mau gak mau harus ada headphone gitu kan jadi hampir semua kami di atas punya headphone karena kalau zoom, zoom meeting di kantor ya mau gak mau harus pakai headphone masak dikencengin kan gak enak ya ganggu yang lain. (kutipan wawancara dari pegawai Kantor Pelayanan Pajak Pratama Tangerang Timur)

Selain itu, adaptasi yang dilakukan oleh pegawai di Kantor Pelayanan Pajak Pratama Tangerang Timur adalah dengan menerima kebiasaan pegawai lain. Hal ini dilakukan agar tercipta keakraban suasana kerja yang nyaman yang dapat meningkatkan minat untuk bekerja.

Nah lama kelamaan mereka saling menerima entah yang satu gak setel musik keras-keras atau yang satu jadi suka musik, nah mereka adaptasi masing-masing aja, karena keadaanya kan sudah terbuka mau gak mau ya harus guyub. (kutipan wawancara dari pegawai Kantor Pelayanan Pajak Pratama Tangerang Timur)

Literatur lain juga menjelaskan hal yang sama, bahwa dalam penerapan open space akan tercipta keterbukaan serta aksesibilitas yang lebih besar, hal ini tentu akan menimbulkan masalah berupa gangguan bagi karyawan (Hedge, 1982). Berdasarkan penelitian tersebut, gangguan yang terjadi bukan berasal dari suara-suara mesin yang terdapat di kantor melainkan dari perilaku karyawan lain. Dengan demikian, para karyawan disarankan untuk beradaptasi dengan mengubah perilaku mereka serta dengan memodifikasi lingkungan.

c. Perselisihan antarpegawai

Penerapan open space merupakan hal yang baru bagi pegawai di Kantor Pelayanan Pajak Pratama Tangerang Timur. Pegawai yang semula menempati cubicle mereka sendiri kemudian dilebur bersama dalam satu meja kerja tanpa sekat mengharuskan mereka untuk bekerja bersama dengan pegawai lainnya. Berdasarkan hasil pengolahan data wawancara diketahui bahwa peleburan yang terjadi dapat menimbulkan gesekan antarpegawai karena setiap pegawai memiliki kebiasaan-kebiasaan tertentu yang mungkin belum bisa diterima oleh pegawai lain. Hal ini terjadi terutama di awal penerapan open space.

Awal-awal memang banyak gesekan, karena kan jadi crowded ya ini, sedangkan semua orang juga berangkat dengan kebiasaan yang berbeda-beda. Ada yang suka dengerin musik, ada yang enggak. Jadi ketika banyak orang dikumpulkan menjadi satu otomatis interaksi sama orang lain lebih sering, gesekan juga pasti akan ada. Awal-awal begitu, 


\section{EDUCORETAX}

Volume 1 No. 1, Maret 2021

tapi sekarang ya sudah normal aja. (kutipan wawancara dari pegawai Kantor Pelayanan Pajak Pratama Tangerang Timur)

Gesekan antarpegawai yang terjadi tidak berlangsung lama. Setelah menerapkan open space selama beberapa waktu, para pegawai dapat beradaptasi dengan kebiasaan pegawai lainnya. Adaptasi yang dapat dilakukan oleh para pegawai di Kantor Pelayanan Pajak Pratama Tangerang Timur merupakan hal yang bertolak belakang dengan literatur. Penelitian yang dilakukan oleh Harris and Associates (1978) menemukan bahwa para pegawai tidak dapat melakukan adaptasi dengan perubahan kantor yang baru (open space) meskipun telah menempati kantor tersebut selama lebih dari enam bulan. Dalam penelitian tersebut dijelaskan bahwa hanya ada 48\% karyawan yang benar-benar merasakan ketenangan dan kenyamanan dalam bekerja. Setelah dilakukan studi lanjutan selama dua tahun, Harris and Associates (1978) menemukan bahwa beberapa karyawan belum dapat beradaptasi dengan perubahan tata ruang kantor tempat bekerja yang baru. Selain itu, penelitian tersebut juga menunjukkan peningkatan jumlah gangguan yang memengaruhi produktivitas karyawan. Jika dibandingkan dengan penelitian terdahulu, tampaknya pegawai di KPP Pratama Tangerang Timur memiliki kemampuan untuk beradaptasi dalam menghadapi tantangan penerapan open space.

Secara umum, tata ruang kerja dalam bentuk open space di KPP Pratama Tangerang Timur serupa dengan konsep Activity Based Workplace (ABW) yang merupakan salah satu program dalam Reformasi Birokrasi Transformasi Kelembagaan Kementerian Keuangan. Dari pembahasan yang disajikan di BAB ini diketahui bahwa penerapan open space memberi dampak dan tantangan bagi pegawai KPP Pratama Tangerang Timur. Pembahasan terkait penerapan open space akan dirangkum pada bagian selanjutnya..

\section{PENUTUP}

Konsep open space yang diterapkan di Kantor Pelayanan Pajak Pratama Tangerang Timur adalah dengan menghilangkan sekat antarpegawai, mengganti cubicle dengan meja besar, serta menambah fasilitas untuk pegawai dan Wajib Pajak. Secara umum, konsep open space yang diterapkan KPP Pratama Tangerang Timur menyerupai konsep Activity Based Workplace yang diatur dalam Keputusan Menteri Keuangan Nomor 91/KMK.01/2021 tentang Implementasi Inisiatif Strategis Program Reformasi Birokrasi dan Transformasi Kelembagaan Kementerian Keuangan. Terdapat sedikit perbedaan dari sisi fleksibilitas pemilihan tempat duduk pegawai. Sesuai ketentuan tersebut, dalam penerapan open space ini seharusnya pegawai bebas memilih tempat untuk bekerja di mana saja, tetapi hal tersebut belum diterapkan di Kantor Pelayanan Pajak Pratama Tangerang Timur.

Dampak positif yang dirasakan oleh pegawai atas diterapkannya kebijakan open space adalah komunikasi dan koordinasi yang meningkat baik itu antarpegawai maupun pegawai dan atasannya, pengawasan yang lebih mudah, space kerja yang lebih luas, serta zero waste dan clean space. Penggantian cubicle menjadi meja besar yang digunakan secara bersamaan membuat pegawai lebih mudah melakukan komunikasi sehingga akan meningkatkan koordinasi satu sama lain. Penghilangan sekat antarpegawai juga memberikan keleluasaan bagi pegawai untuk dapat melakukan pengawasan antarpegawai maupun pegawai dan atasannya. Selain itu, sekat yang telah dihilangkan dan diganti dengan meja besar membuat ruangan terkesan menjadi lebih luas. Konsep open space yang menggunakan meja besar sebagai meja kerja untuk beberapa pegawai sekaligus membuat pegawai tidak dapat meletakkan terlalu banyak barang, selain barang yang memang berhubungan dengan pekerjaan.

Salah satu dampak negatif yang dirasakan oleh sebagian pegawai ini adalah space, dalam hal ini adalah meja kerja, yang lebih kecil atau sempit. Penggantian cubicle dengan meja besar mengharuskan para pegawai untuk berbagi satu meja kerja tersebut dengan beberapa pegawai lain. Hal ini membuat pegawai merasa tidak leluasa untuk melakukan pekerjaannya. 


\section{EDUCORETAX}

Volume 1 No. 2, Juni 2021

Selain itu, batasan wilayah kerja antarpegawai juga menjadi tidak teratur. Hal ini membuat pegawai merasa kesulitan untuk menempatkan barang atau berkas yang berhubungan dengan pekerjaan mereka, khususnya pegawai yang masih memerlukan berkas fisik dalam pekerjaan mereka, seperti pemeriksa pajak.

Beberapa tantangan yang dihadapi pegawai dari penerapan open space adalah privasi yang menjadi terbatas, meningkatnya distraksi atau gangguan, dan terjadinya perselisihan antarpegawai. Satu hal yang bisa diambil sebagai pelajaran penting dari pengalaman KPP Pratama Tangerang Timur dalam menghadapi tantangan tersebut adalah kemauan pegawai untuk beradaptasi dan mencari cara dalam mengatasi tantangan dalam penerapan open space. Penelitian yang telah dilakukan mengenai penerapan, dampak, tantangan dan solusi atas open space di lingkungan Kantor Pelayanan Pajak Pratama Tangerang Timur memberikan gambaran bahwa Kantor Pelayanan Pajak Pratama telah mampu untuk menerapkan konsep tata ruang ini sebagai alternatif penataan ruang yang lebih nyaman dan memberikan dampak baik untuk pegawai. Meskipun terdapat beberapa dampak negatif dan tantangan dari penerapannya, hal tersebut dapat ditangani dengan baik oleh para pegawai..

\section{DAFTAR PUSTAKA}

Afifah, N. A. (2019). Pengaturan Layout Kantor Terbuka yang Efektif dan Efisien bagi Perusahaan Startup. Academia Edu. https://www.academia.edu/download/58147244/JURNAL_NURUL_AZMI_175211020_P OLBAN.pdf.

Allen, T. J., \& Gerstberger, P. G. (1973). A Field Experiment to Improve Communications in a Product Engineering Department: The Nonterritorial Office. Human Factors, 15(5), 487498.

Arge, K. (2005). Adaptable Office Buildings: Theory and Practice. Facilities, 23, 119-127.

Boyatzis, R. E. (1998). Transforming Qualitative Information. California: Sage.

Central Transformation Office Kementerian Keuangan. (2019). Pendampingan Piloting Activity Based Workplace di Kemenkeu [PowerPoint slides].

Earle, H. A. (2003). Building a Workplace of Choice: Using the Work Environment to Attract and Retain Top Talent. Journal of Facilities Management, 2, 244-257.

Hariani, A. (2019). Ruang Kerja Terbuka dan Digitalisasi Berkas. Majalah Pajak.net: https://majalahpajak.net/ruang-kerja-terbuka-dan-digitalisasi-berkas/

Harris and Associates, L. (1978). The Steelcase National Study of Office Environments: Do They Work?. Washington: Steelcase Inc.

Hassanain, M. A. (2006). Factors Affecting the Development of Flexible Workplace Facilities. Journal of Corporate Real Estate, 8, 213-220.

Hedge, A. (1982). The open-plan office: A systematic investigation of employee reactions to their work environment. Environtment and Behavior, 14(5), 519-542.

Irving, G. L. (2016). Collaboration in Open-Plan Offices. [Doctoral dissertation, University of Queensland]. Research Direct.

Junaid, I. (2016). Analisis Data Kualitatif dalam Penelitian Pariwisata. Jurnal Kepariwisataan, 10(1), 59-74.

Kornberger, M., \& Clegg, S. R. (2004). Bringing Space Back In: Organizing the Generative Building. Organization Studies, 25(7), 1095-1114.

Marans, R. W., \& Yan, X.-y. (1989). Lighting Quality and Environmental Satisfaction in Open Space and Enclosed Offices. Journal of Architectural and Planning Research, 6(2), 118131.

Masram, \& Mu'ah. (2017). Manajemen Sumber Daya Manusia. Surabaya: Zifatama.

Nasution, A. (1995). Prosedur Penelitian Kualitatif. Jakarta: Pusat Jaya. 


\section{EDUCORETAX}

Volume 1 No. 1, Maret 2021

Prabawani, B., \& Sungkar, J. V. (2018). Analisis Collaborative Office Space Dalam Upaya Peningkatan Kepuasan Kerja Karyawan. Jurnal Ilmu Administrasi Bisnis. 7(3), 415-423.

Rivai, V., \& Mulyadi, D. (2007). Kepemimpinan dan Perilaku Organisasi. Jakarta: PT. Raja Grafindo Persada.

Robbins, S. P., \& Coulter, M. (2018). Management. New Jersey: Pearson.

Saleem, A., Shah, A. A., Zaman, K., Arif, M., Shehzad, K., \& Ullah, I. (2012). Impact of Interior Physical Environment on Academicians' Productivity in Pakistan. Iranian Journal of Management Studies (IJMS), 5(1), 25-46.

Santoso, R. (2020). Tinjauan Penerapan Flexi Working Time dan Flexi Working Space di Direktorat Jenderal Pajak. [Unpublished research paper]. Politeknik Keuangan Negara STAN.

Saunders, M., Lewis, P., \& Thornhill, A. (2019). Research Methods for Business Students. United Kingdom: Pearson Education.

Sedarmayanti. (2009). Tata Kerja \& Produktivitas Kerja. Bandung: Mandar Maju.

Semiawan, C. R. (2010). Metode Penelitian Kualitatif Jenis, Karakteristik, dan Keunggulannya. Jakarta: Grasindo.

Sundstrom, E., Town, J. P., Rice, R. W., Osborn, D. P., \& Brill, M. (1994). Office Noise, Satisfaction, and Performance. Environment and Behavior, 26(2), 195-222.

Thanem, T., Varlander, S., \& Cummings, S. (2011). Open Space = Open Minds? The Ambiguities of Pro-Creative Office Design. International Journal of Work Organisation and Emotion, 4(1), 78-98.

Direktorat Jenderal Pajak. (2007). Keputusan Direktur Jenderal Pajak Nomor 112 Tahun 2007 Tentang Penerapan Organisasi, Tata Kerja, dan Saat Mulai Beroperasinya Kantor Pelayanan Pajak Pratama dan Kantor Pelayanan, Penyuluhan dan Konsultasi Perpajakan di Lingkungan Kantor Wilayah Direktorat Jenderal Pajak Banten.

Direktorat Jenderal Pajak. (2007). Surat Edaran Nomor 19 Tahun 2007 Tentang Persiapan Penerapan Sistem Administrasi Perpajakan Modern pada Kantor Wilayah DJP dan Pembentukan Kantor Pelayanan Pajak Pratama di Indonesia Tahun 2007-2008.

Kementerian Keuangan. (2020). Keputusan Menteri Keuangan Nomor 125 Tahun 2020 Tentang Implementasi Inisiatif Strategis Program Reformasi Birokrasi dan Transformasi Kelembagaan Kementerian Keuangan.

Kementerian Keuangan. (2020). Peraturan Menteri Keuangan Nomor 184 Tahun 2020 Tentang Perubahan atas Peraturan Menteri Keuangan Nomor 210/PMK.01/2017 Tentang Organisasi dan Tata Kerja Instansi Vertikal Direktorat Jenderal Pajak.

Kementerian Keuangan Republik Indonesia. (2021). Keputusan Menteri Keuangan Nomor 91 Tahun 2021 Tentang Implementasi Inisiatif Strategis Program Reformasi Birokrasi dan Transformasi Kelembagaan Kementerian Keuangan. 